\title{
MEMADUKAN KONSEP STANDAR BIAYA KELUARAN UMUM RISET DENGAN FLEKSIBILITAS PERTANGGUNGJAWABAN PENGGUNAAN DANA
}

\section{Niken Ajeng Lestari}

Email: niken3010@gmail.com

\section{PENDAHULUAN}

\subsection{Latar Belakang}

Dalam rangka penyusunan Standar Biaya Keluaran yang bersifat umum atau SBK yang berlaku di seluruh Kementerian Negara dan Lembaga (SBKU), terdapat perilaku ekonomi dari suatu kelompok tertentu atau unit yang ditengarai akan menunjukkan perilaku yang tidak bertanggung jawab dalam melaksanakan suatu kegiatan yang didanai dari anggaran pemerintah. Kegiatan tersebut adalah riset atau penelitian yang pengalokasian dananya melalui SBK.

Perilaku yang diperkirakan akan terjadi terkait kegiatan riset adalah perilaku di ranah pertanggungjawaban pelaksanaan kegiatan, dimana penerima dana riset, secara sengaja atau tidak, cenderung akan mencari-cari nota atau tanda bukti pembayaran lainnya untuk dijadikan lampiran pertanggungjawaban dananya. Hal ini terjadi karena berdasarkan pengalaman beberapa peneliti, terdapat pengeluaran riset yang tidak terduga baik dalam jumlah yang besar maupun kecil dengan intesitas yang cukup sering.

Berdasarkan dugaan tersebut, pengalokasian dana melalui SBK justru dinilai kurang efektif karena justru akan mendorong perilaku yang kurang bertanggung jawab. Atas permasalahan tersebut, terdapat solusi yang ditawarkan diantaranya adalah penerapan fleksibilitas pertanggungjawaban penggunaan dana untuk SBKU riset sehingga dana yang diberikan untuk kegiatan riset berlaku selayaknya dana pengadaan barang/jasa kepada pihak ketiga yang pertanggungjawabnya berupa kontraktual antara peneliti dan pemilik dana dengan batas waktu tertentu.

Selain itu, fleksibilitas pertanggungjawaban dana bagi SBKU riset juga dilatarbelakangi oleh suatu permasalahan yang dihadapi para peneliti dalam melakukan pelaporan keuangan. Permasalahan tersebut diungkapkan oleh Kemenristekdikti dalam kajiannya mengenai perbaikan manajemen anggaran riset yaitu peneliti harus melaporkan pertanggungjawaban keuangannya secara individu. Hal ini cukup memberatkan mengingat SPJ yang harus dilakukan adalah mulai dari pengadaan barang dan jasa, pemberian honor, pembayaran pajak, dan perjalanan dinas. Penyusunan SPJ dirasa lebih sulit daripada melakukan penelitian itu sendiri. Di sisi lain, hal ini membuat fokus peneliti terpecah dan pada akhirnya dapat berefek pada rendahnya kualitas riset yang dihasilkan.

Dilatarbelakangi oleh beberapa hal tersebut, kajian ini disusun untuk mengkaji 
lebih lanjut mengenai memadukan konsep SBKU riset dengan fleksibilitas pertanggungjawaban dananya. Analisis akan dilakukan dengan metode kualitatif dengan menguraikan terlebih dahulu konsep dari fleksibilitas pertanggungjawaban penggunaan dana SBKU riset, kemudian mengkajinya dari sisi peraturan perundang-undangan, urgensi, manfaat dan kendala dari konsep fleksibilitas pertanggungjawaban dana bagi SBKU riset.

\subsection{Pertanyaan Penelitian}

Terdapat beberapa pertanyaan yang ingin dijawab dari penyusunan kajian ini, diantaranya adalah:

1. Bagaimana konsep fleksibilitas pertanggungjawaban penggunaan dana SBKU riset?

2. Bagaimana kemungkinan dari sisi peraturan perundang-undangan mengenai fleksibilitas pertanggungjawaban penggunaan dana bagi SBKU riset?

3. Apa urgensi dari penerapan fleksibilitas pertanggungjawaban penggunaan dana bagi SBKU riset?

4. Apa saja isu-isu yang muncul dengan adanya fleksibilitas pertanggungjawaban penggunaan dana bagi SBKU riset?

\subsection{Tujuan penelitian}

Berdasarkan beberapa pertanyaan tersebut, penyusunan kajian ini bertujuan untuk:

1. Menguraikan konsep SBKU riset yang akan dibentuk.

2. Mengetahui kemungkinan dari sisi peraturan perundang-undangan mengenai fleksibilitas pertanggungjawaban penggunaan dana bagi SBKU riset.

3. Mengetahui urgensi dari penerapan fleksibilitas pertanggungjawaban penggunaan dana bagi SBKU riset.

4. Mengetahui isu-isu yang muncul dengan adanya fleksibilitas pertanggungjawaban penggunaan dana bagi SBKU riset.

\section{TINJAUAN PUSTAKA}

\subsection{Kebijakan Standar Biaya Keluaran}

SBK adalah besaran biaya uang ditetapkan untuk menghasilkan keluaran (output)/sub keluaran (sub output). SBK dapat terdiri atas:

3. Indeks biaya keluaran yaitu SBK untuk menghasilkan satu volume keluaran (output), dan

4. Total biaya keluaran adalah SBK untuk menghasilkan total volume keluaran (output).

Penyusunan SBK dilakukan pada level keluaran (output)/sub keluaran (sub output) yang menjadi tugas dan fungsi $\mathrm{K} / \mathrm{L}$. Keluaran (output)/sub keluaran (sub output) yang dapat diusulkan menjadi SBK mempunyai beberapa kriteria yaitu:

1. Bersifat berulang

2. Mempunyai jenis dan satuan yang jelas serta terukur, dan

3. Mempunyai komponen/tahapan yang jelas.

SBK dalam proses penganggaran berfungsi sebagai.

1. Batas tertinggi yang besarannya tidak dapat dilampaui,

2. Referensi penyusunan prakiraan maju,

3. Bahan penghitungan pagu indikatif $\mathrm{K} / \mathrm{L}$, dan/atau 
4. Referensi penyusunan SBK untuk keluaran (output) sejenis pada $\mathrm{K} / \mathrm{L}$ yang berbeda.

Di sisi lain, dalam rangka pelaksanaan anggaran, SBK berfungsi sebagai estimasi yaitu prakiraan besaran biaya yang dapat dilampaui, antara lain karena perubahan komponen/tahapan dan/atau penggunaan standar biaya yang dipengaruhi harga pasar.

SBK berlaku untuk beberapa/seluruh K/L yang penetapannya oleh Menkeu dengan terlebih dahulu berkoordinasi dengan $\mathrm{K} / \mathrm{L}$, atau juga berlaku untuk satu $\mathrm{K} / \mathrm{L}$ tertentu yang penetapannya oleh Menkeu berdasarkan usulan dari pimpinan K/L atau pejabat yang berwenang dengan mengatasnamakan pimpinan K/L. SBK yang berlaku untuk beberapa $\mathrm{K} / \mathrm{L}$ disebut sebagai Standar Biaya Keluaran Khusus (SBKK) dan SBK yang berlaku untuk seluruh $\mathrm{K} / \mathrm{L}$ disebut sebagai Standar Biaya Keluaran Umum (SBKU).

Dalam penyusunan SBK, diperlukan adanya komponen/tahapan dengan tujuan untuk mengetahui:

1. Proses pencapaian keluaran/sub keluaran yang akan dihasilkan,

2. Relevansi terhadap pencapaian keluaran/sub keluaran, baik terhadap volume maupun kualitasnya,

3. Keterkaitan dan kesesuaian antar tahapan dalam mendukung pencapaian keluaran/sub keluaran.

Secara umum, komponen/tahapan dalam pencapaian suatu keluaran/sub keluaran menggambarkan pelaksanaan fungsi manajemen yang terdiri dari:

1. Perencanaan (planning),

2. Pengorganisasian (organizing),

3. Pelaksanaan (actuating), dan
4. Monitoring, evaluasi, dan pelaporan (controlling).

\subsection{Pertanggungjawaban Penggunaan Dana APBN}

Dalam Peraturan Pemerintah Nomor 45 Tahun 2013 tentang Tata Cara Pelaksanaan APBN, penyelesaian tagihan kepada negara atas suatu beban anggaran belanja negara yang tertuang dalam APBN, dilaksanakan berdasarkan hak dan bukti yang sah untuk memperoleh pembayaran. Pembayaran atas tagihan kepada negara dilakukan secara langsung dari rekening kas umum negara kepada yang berhak.

Berdasarkan tagihan kepada negara, pejabat pembuat komitmen (PPK) menerbitkan dan menandatangani surat permintaan pembayaran (SPP) yang selanjutnya diuji terlebih dahulu oleh pejabat penandatangan surat perintah membayar (PPSPM) sebelum diterbitkan surat perintah membayar (SPM) yaitu dokumen yang diterbitkan pengguna anggaran/kuasa pengguna anggaran (PA/KPA) atau pejabat lain yang ditunjuk untuk mencairkan dana yang bersumber dari DIPA atau dokumen lain yang dipersamakan. Pengujian SPP yang dilakukan oleh PPSPM tersebut meliputi:

a. Pemeriksaan secara rinci kelengkapan dokumen pendukung SPP,

b. Penelitian ketersediaan pagu anggaran dalam dokumen isian pelaksanaan anggaran (DIPA),

c. Pemeriksaan kesesuaian keluaran antara yang tercantum dalam dokumen perjanjian dengan keluaran yang tercantum dalam DIPA,

d. Pemeriksaan kebenaran atas hak tagih, paling sedikit meliputi: 
1) Pihak yang ditunjuk untuk menerima pembayaran,

2) Nilai tagihan yang harus dibayar, dan

3) Jadwal waktu pembayaran.

e. Pemeriksaan kesesuaian pencapaian keluaran antara spesifikasi teknis yang disebutkan dalam dokumen penerimaan barang/jasa dan spesifikasi teknis yang disebutkan dalam dokumen perjanjian, dan

f. Pemeriksaan dan pengujian ketepatan penggunaan klasifikasi anggaran.

Dalam hal hasil pengujian sebagaimana dimaksud di atas tidak memenuhi persyaratan, PPSBM wajib menolak menerbitkan SPM.

\subsection{Bagan Akun Standar}

Bagan Akun Standar yang selanjutnya disingkat BAS adalah daftar kodefikasi dan klasifikasi terkait transaksi keuangan yang disusun secara sistematis sebagai pedoman dalam perencanaan, penganggaran, pelaksanaan anggaran, dan pelaporan keuangan pemerintah. Kodefikasi ini digunakan dalam sistem yang terintegrasi. Integrasi dilaksanakan dengan penggunaan klasifikasi atau kode pengukuran yang sama untuk setiap tahapan dalam siklus pengelolaan keuangan negara. Melalui penggunaan klasifikasi yang sama pada tahapan perencanaan, penganggaran hingga pertanggungjawaban, Bagan Akun Standar merupakan suatu pedoman dalam pencatatan seluruh transaksi keuangan pemerintah. Selain itu, Bagan Akun Standar digunakan sebagai pusat aliran data dari sistem pengelolaan keuangan, alat pengendalian disiplin fiskal melalui pengaturan pengendalian dan kerangka struktur pelaporan, dan mendukung proses pengambilan keputusan pemerintah yang lebih baik.

Penetapan pengunaan Bagan Akun Standar sebagai pedoman dalam mekanisme pengelolaan keuangan negara didahului dengan pembentukan suatu kerangka dasar dalam bentuk single framework Bagan Akun Standar. Dengan adanya single framework ini, maka Bagan Akun Standar memfasilitasi kebutuhan klasifikasi para penggunanya. Bagan Akun Standar tidak hanya menyajikan akun yang secara umum digunakan untuk tujuan pelaporan keuangan seperti akun aset, kewajiban, modal, pendapatan, belanja, pembiayaan, dan lain-lain, tetapi juga meliputi klasifikasi lain yang digunakan dalam perencanaan dan penganggaran. Klasifikasi tersebut antara lain berupa kode organisasi, tempat pembayaran, lokasi kegiatan, program, kegiatan dan output yang dihasilkan. Penggunaan klasifikasi yang sama tersebut, memerlukan kesepakatan dan komitmen antar pengguna Bagan Akun Standar.

Komitmen para pengguna Bagan Akun Standar baik dari Kementerian Keuangan, maupun Kementerian Negara/Lembaga sangat diperlukan guna mewujudkan amanat reformasi keuangan negara dan mendukung proses integrasi pengelolaan keuangan negara. Untuk memenuhi hal tersebut, maka dibutuhkan pembaruan terhadap pengelolaan keuangan Negara guna memenuhi prinsipprinsip good governance. Pemutakhiran Bagan Akun Standar dilaksanakan secara terpadu dengan mendasarkan pada single framework tersebut. Selain itu, penggabungan klasifikasi anggaran dan klasifikasi akuntansi membentuk 
kumpulan kode berupa struktur Bagan Akun Standar.

Klasifikasi dalam BAS terdiri dari segmen yang merupakan bagian dari BAS berupa rangkaian kode sebagai dasar validasi transaksi keuangan yang diakses oleh sistem aplikasi. Segmen dalam BAS terdiri dari 12 segmen yaitu segmen:

a. Satker merupakan kode satker dengan atribut antara lain berupa kode bagian anggaran dan kode eselon I yang mencerminkan adanya unit yang bertanggung jawab dalam pencatatan transaksi,

b. KPPN merupakan kode KPPN dengan atribut antara lain berupa kode Kantor Wilayah Direktorat Jenderal Perbendaharaan. Segmen ini menunjukan adanya fungsi tempat pemrosesan pembayaran melalui kantor pelayanan perbendaharaan di bawah Ditjen Perbendaharaan Kementerian Keuangan,

c. Akun merupakan kode akun. Kode akun atau juga dikenal sebagai klasifikasi ekonomi, merupakan salah satu bagian penting yang menunjukan transaksi dan dampaknya pada laporan keuangan. Kode akun ini akan mengalami perubahan karena adanyapenerapan akuntansi berbasis akrual sehingga akun-akun yang ada akan menjadi akun akrual. Dalam penerapan akuntansi akrual, terdapat beberapa laporan yang membutuhkan kode akun baru atau juga terkait dengan mapping dengan akun operasional berbasis kas yang sudah ada,

d. Program merupakan kombinasi dari kode bagian anggaran, kode eselon I, dan kode program yang menunjukkan penjabaran kebijakan Kementerian
Negara/Lembaga yang terdiri atas beberapa kegiatan,

e. Output akan melekat pada pelaksanaan dan pencapaian suatu kegiatan, sehingga output merupakan kombinasi dari kode kegiatan dan kode output, dengan atribut antara lain berupa kode fungsi dan kode sub fungsi,

f. Dana merupakan kombinasi dari kode sumber dana, kode cara penarikan, dan kode nomor register yang mencerminkan adanya alokasi pelaksanaan anggaran yangberasal dari sumber dana tertentu dan memiliki cara penarikan dana yangsesuai dengan sumber dana tersebut,

g. Bank merupakan kombinasi dari kode tipe rekening dan kode nomor rekening dengan atribut antara lain berupa kode KPPN yang mencerminkan penggunaan rekening bank berbeda dalam pengelolaan anggaran oleh pemegang kas pemerintah yaitu Kuasa BUN yang dalam hal ini dilakukan oleh Direktorat Pengelolaan Kas Negara selaku Kuasa BUN Pusat, dan KPPN selaku Kuasa BUN Daerah,

h. Kewenangan merupakan kode kewenangan sebagai cerminan terdapat berbagai kewenangan dalam proses pelaksanaan anggaran. Terdapat 6 kewenangan yaitu kewenangan kantor pusat, kator daerah, dekonsentrasi, tugas pembantuan, desentralisasi, dan urusan bersama,

i. Lokasi merupakan kode Lokasi menunjukkan tempat berlangsungnya kegiatan dan/atau penerima dana. Selain itu, dengan adanya kode lokasi, maka terdapat pengendaliananggaran atas alokasi pembagian Dana Bagi Hasil, dan bertujuan untuk transparansi 
pengalokasian dana dalam transaksi pengelolaan keuangan daerah,

j. Anggaranmerupakan kode anggaranyang menunjukkan beberapa tahapan pencatatan transaksi keuangan dalam siklus pengelolaan APBN. Tahapan tersebut terdiri dari atas transaksi APBN, DIPA, realisasi, pengembalian realisasi, dan penyesuaian akrual,

k. Antarentitasmerupakan kode antarentitas yang berisi Ditagihkan Kepada Entitas Lain (Due to) dan Diterima Dari Entitas Lain (Due From) sebagai lawan dari kode satker untuk transaksi antar entitas, dan

I. Cadangan merupakan kodefikasi yang disediakan jika nantinya dalam pengembangan BAS ke depan akan membutuhkan segmen baru yang belum tertampung dalam segmen kodefikasi BAS saat ini.

\subsection{Pengajuan Riset kepada Kementerian}

Riset, Teknologi, dan Perguruan Tinggi

Pengajuan riset pada Kemenristekdikti mengikuti pedoman Insentif Riset Sistem Inovasi Nasional (SINas) yang berisi prosedur pengajuan riset yang akan didanai dari APBN dan kriteria-kriteria yang harus dipenuhi. Berikut alur pengajuan riset yang dibiayai oleh APBN melalui Kemenristekdikti.

\section{Gambar 1. Prosedur Pengajuan Proposal Insentif Riset SINas pada Kemenristekdikti}
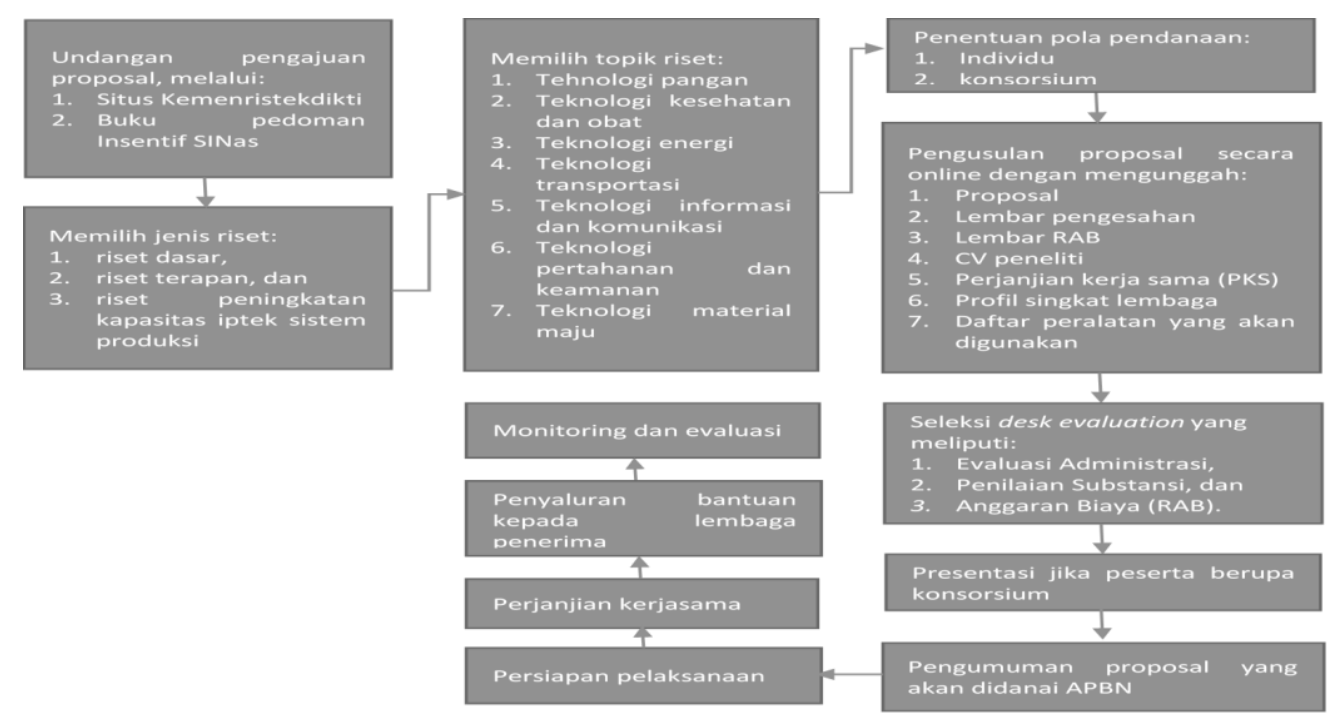

Pada prosedur tersebut, proses kerjasama riset serupa dengan proses pengadaan barang dan jasa dilihat dari kewajiban yang harus dipenuhi oleh pengaju proposal. Berikut kewajiban yang harus dipenuhi oleh pengaju proposal insentif riset pada Kemenristekdikti yaitu lembaga penerima berkewajiban untuk:

1. Mengembangkan organisasi dan sistem manajemen yang efektif, dan

efisien serta accountable untuk pelaksanaan kegiatan,

2. Melaksanakan rencana yang telah disusun untuk mencapai sasaran dan keluaran yang telah ditentukan, serta memenuhi semua ketentuan yang diatur di dalam kontrak kerjasama dengan tim pengelola insentif riset SINas, 
3. Pelaksanaan insentif riset SINas selama 10 (sepuluh) bulan kalender,

4. Bila terjadi keterlambatan penyampaian pelaporan akhir atau tidak selesai sesuai jangka waktu yang telah ditetapkan akan dikenakan denda sebesar $1 \%$ o (satu per seribu) untuk setiap hari keterlambatan atau maksimum 5\% (lima persen) dari nilai kontrak dan atau sangsi lain sesuai peraturan perundang yang berlaku.

5. Pencairan dana penyampaian laporan (hardcopy dan file elektronik), yaitu:

a. Proposal untuk pencairan dana termin 1 (30\%). Dana diberikan setelah menyampaikan proposal hasil perbaikan sesuai anggaran yang disetujui dan dokumen administrasi keuangan.

b. Laporan Kemajuan Pertama untuk penarikan dana termin 2 (50\%). Dana diberikan setelah menyampaikan laporan kemajuan teknis pertama setara dengan pemanfaatan dana30\%.

c. Laporan Kemajuan Kedua Untuk penarikan dana Termin 3 (20\%). Dana diberikan setelah menyampaikan laporan kemajuan Teknis kedua setara dengan pemanfaatan dana $50 \%$.

d. Laporan akhir setara pemanfaatan dana $100 \%$ Disampaikan saat kontrak kerjasama berakhir yang meliputi: (1) Laporan Akhir Teknis, (2) Laporan Ringkas Hasil Litbang Sesuai Lampiran 7, (3) Daftar Hasil Litbang, (4) Surat Pernyataan Tidak Membeli Alat/Barang Modal, (5) Surat Pernyataan Setor Dana Sisa, Dilengkapi dengan Bukti Setor Dana
Sisa (Bila ada), serta (6) Hasil Evaluasi.

6. Membangun dan memantapkan kemitraan dengan sejumlah lembaga penelitian, perguruan tinggi, industri, serta institusi lain yang terkait.

7. Mengamankan dan mengelola teknologi yang dihasilkan melalui perlindungan HKI meliputi: paten, hak cipta, desain industri, rahasia dagang, dan sebagainya.

8. Melakukan langkah promosi hasil litbang potensial:

a. Mengembangkan mekanisme transformasi teknologi dan menyediakan dukungan teknis, agar hasil litbang yang dibiayai khususnya melalui Insentif Riset SINas dapat diadopsi oleh pengguna, industri atau masyarakat secara maksimal.

b. Melaporkan kemajuan kegiatan, hambatan dan penyimpangan yang terjadi kepada Kementerian Riset Dan Teknologi Secara periodik.

c. Menyediakan Informasi yang diperlukan dalam rangka monitoring dan evaluasi kinerja Insentif Riset SINas.

d. Mengikuti pameran Iptek dan seminar yang diselenggarakan Kementerian Riset dan Teknologi.

\section{METODOLOGI PENELITIAN}

Metode penelitian yang digunakan dalam menyusun kajian ini adalah metode kualitatif. Substansi yang dikaji diperoleh melalui studi literatur mulai dari peraturan perundang-undangan, kajian terdahulu, serta berbagai literatur yang relevan dengan tema kajian ini. 


\section{PEMBAHASAN}

\section{1}

Konsep

Pertanggungjawaban

Dana SBKU Riset

Konsep fleksibilitas

pertanggungjawaban penggunaan dana untuk SBKU riset, adalah serupa dengan penerapan pada akun belanja lain-lain. Belanja lain-lain yaitu pengeluaran/belanja pemerintah pusat yang sifat pengeluarannya tidak dapat diklasifikasikan ke dalam pos-pos pengeluaran lainnya (pegawai, barang, modal, pembayaran utang/kewajiban, subsidi, hibah, dan bantuan sosial). Pertanggungjawaban atas penggunaan dana SBKU riset adalah pertanggungjawaban yang berupa penggunaan dana secara gelondongan dan tidak perlu terdapat bukti-bukti pembayaran suatu barang/jasa yang digunakan seperti nota, kuitansi, dan struk. Pertanggungjawaban atas penggunaan dana riset hanya berupa kesepakatan antara pihak-pihak yang berkepentingan. Kesepakatan tersebut berisi diantaranya progress penyelesaian riset, persentase dana yang dapat dicairkan per progress riset, waktu penyelesaian riset, tenggat waktu keterlambatan, konsekuensi apabila riset terlambat diselesaikan atau tidak dapat diselesaikan, dan hal lainnya yang mengikat bagi penerima insentif riset.

Hal ini menimbulkan beberapa pertanyaan atau isu yang memunculkan pro dan kontra atas penerapan fleksibilitas pertanggungjawaban penggunaan dana bagi SBKU riset. Isu-isu yang muncul akan dibahas lebih lanjut pada subbab berikutnya dan selanjutnya digunakan untuk menilai seberapa layaknya pembentukan akun khusus SBKU riset dalam pengelolaan keuangan negara.

\subsection{Analisis Penerapan Fleksibilitas Pertanggungjaaban Penggunaan Dana SBKU Riset}

\subsubsection{Aspek Hukum}

Pada subbab ini, analisis penerapan fleksibilitas pertanggungjawaban penggunaan dana SBKU riset dilihat dari sisi hukum atau peraturan perundangundangan yang berlaku. Beberapa peraturan yang berkaitan diantaranya adalah peraturan yang berkenaan dengan BAS, pelaksanaan APBN, dan peraturan lainnya yang relevan.

Dimulai dari Pasal 65 ayat (1) Peraturan Pemerintah No.45 Tahun 2013 tentang Tata Cara Pelaksanaan APBN, dalam hal penyelesaian tagihan kepada negara atas suatu beban anggaran belanja negara yang tertuang dalam APBN, dilaksanakan berdasarkan hak dan bukti yang sah untuk memperoleh pembayaran. Pada pasal tersebut, pertanggungjawaban atas suatu penggunaan dana dari APBN, tidak mensyaratkan dokumen yang sangat rinci. Hanya dipersyaratkan hak dan bukti yang sah untuk memperoleh pembayaran.

Beberapa hal yang perlu dipastikan dalam pengajuan SPP diuraikan dalam pasal 67 yaitu saat PPSPM menguji SPP atas suatu tagihan tertentu, harus melakukan pengujian yang meliputi kelengkapan dokumen SPP, ketersediaan pagu anggaran dalam DIPA, kesesuaian keluaran antara dokumen perjanjian dengan DIPA, kebenaran hak tagih, kesesuaian keluaran antara dokumenn 
penerimaan barang/jasa dengan dokumen perjanjian, dan ketepatan penggunaan klasifikasi anggaran.

Analisis lain dari sisi hukum selanjutnya adalah analisis dengan memperhatikan

PMK No.214/PMK.05/2013 tentang Bagan Akun Standar. Peraturan ini juga perlu diperhatikan karena pada penerapannya, diharapkan dibentuk akun khusus bagi SBKU riset sehingga dari sisi akuntansi akan lebih akuntabel.

$$
\text { Pada pasal } 5 \text { PMK }
$$

No.214/PMK.05/2013 disebutkan bahwa BAS dikelola oleh DJPB. Dalam rangka pengelolaan BAS tersebut, DJPB dapat melakukan pemutakhiran BAS yang dilakukan atas dasar usulan dan/atau penetapan kebijakan.

Berdasarkan hal tersebut, usulan pemutakhiran BAS dapat berasal dari $\mathrm{K} / \mathrm{L}$ dan/atau unit eselon I di lingkungan Kemenkeu. Usulan tersebut disampaikan kepada DJPB/DJA/DJPU sesuai dengan jenis segmen-segmennya. Selain itu, pemutakhiran BAS atas dasar penetapan kebijakan dapat disebabkan antara lain karena perubahan peraturan perundangundangan dan/atau perubahan proses bisnis pengelolaan keuangan.

Berdasarkan beberapa analisis dari sisi hukum tersebut di atas, penerapan fleksibilitas pertanggungjawaban penggunaan dana untuk SBKU riset tidak memiliki permasalahan yang berarti. Hanya perlu terdapat koordinasi antara pihak-pihak terkait terutama DJPB sebagai pengelola BAS. Selain itu juga diperlukan sosialisasi bagi seluruh pengelola keuangan negara terkait hal ini mengingat SBKU akan berlaku bagi seluruh $\mathrm{KL}$. Di samping itu, juga perlu terdapat komunikasi intensif dengan aparat dan pemeriksa agar memiliki cara pandang yang sama pada saat melakukan audit atas pelaksanaan kegiatan dalam rangka pencapaian output riset.

\subsubsection{Aspek Urgensi}

Analisis selanjutnya mengenai rencana penerapan fleksibilitas pertanggungjawaban penggunaan dana bagi SBKU riset ialah dengan mengkaji urgensi dari hal tersebut. Dengan adanya pertanggungjawaban secara "global" atau tanpa pertanggungjawaban yang sangat rinci dari penggunaan dana insentif riset, hal ini akan memudahkan para peneliti dalam proses penyusunan risetnya.

Bentuk pertanggungjawaban secara global akan mendukung kinerja peneliti dalam melakukan riset baik dari sisi kuantitas maupun kualitas riset yang dihasilkan. Dengan fokus pada penyusunan risetnya, hal ini mendorong para peneliti untuk menyusun riset sebanyakbanyaknya dan peneliti akan lebih fokus pada kualitas risetnya daripada sibuk menyediakan segala bentuk nota atau kuitansi sebagai bentuk pertanggungjawaban atas penggunaan dana riset.

Berdasarkan pertimbanganpertimbangan tersebut, dilihat dari urgensinya, maka penerapan fleksibilitas pertanggungjawaban penggunaan dana bagi SBKU riset dapat dilakukan. Namun perlu ditekankan pada para peneliti bahwa dengan konsep pertanggungjawaban tersebut, harus tetap mengedepankan asas pengelolaan keuangan negara sebagaimana diungkapkan dalam UU No.17 Tahun 2003 yaitu keuangan negara 
dikelola secara tertib, taat pada peraturan perundang-undangan, efisien, ekonomis, efektif, transparan, dan bertanggung jawab dengan memperhatikan rasa keadilan dan kepatutan.

\subsubsection{Isu-Isu yang Muncul Pada Penerapan Fleksibilitas Pertanggungjawaban Penggunaan Dana SBKU Riset}

Dari beberapa uraian di atas, terdapat aspek lain yang perlu diperhatikan dalam melakukan analisis penerapan fleksibilitas pertanggungjawaban penggunaan dana bagi SBKU riset. Aspek tersebut adalah perlunya memperhatikan isu-isu yang muncul dari penerapan fleksibilitas pertanggungjawaban penggunaan dana yang tidak dapat diabaikan dan perlu terdapat solusinya. Terdapat 3 isu yang akan dibahas satu per satu dalam subbab ini yaitu berkenaan dengan penentuan besaran SBKU riset itu sendiri, akuntabilitas, dan pengukuran kinerja.

\section{a. Penentuan Besaran SBKU Riset}

Pembahasan akan dimulai dari isu bagaimana besaran SBKU riset itu disusun. Isu yang muncul adalah apakah besaran SBKU riset yang telah ditetapkan, sudah dapat menjamin bahwa kebutuhan riset telah dapat terpenuhi. Sementara itu, jenis riset yang ada sangat beragam dan membawa konsekuensi kebutuhan dananya juga cukup beragam pula. Isu ini mungkin tidak berhubungan langsung dalam pertimbangan untuk menentukan pembentukan akun khusus bagi SBKU riset, namun hal ini menjadi penting untuk memastikan besaran SBKU adalah angka yang dinilai paling efisien dan optimal sehingga pertanggungjawaban secara global dari penggunaan dana ini tidak terdapat pro-kontra lagi.

Berikut beberapa uraian mengenai penentuan besaran SBKU riset. SBKU ditetapkan oleh Menteri Keuangan dan berlaku bagi seluruh kementerian dan/atau lembaga. Agak berbeda dengan konsep penggunaan besaran SBM dan SBK dalam perencanaan dan pelaksanaan anggaran, khusus besaran SBKU riset, dalam proses perencanaan dan pelaksanaan adalah batas tertinggi yang tidak dapat dilampaui. Artinya, alokasi SBKU dalam proses perencanaan tidak boleh melebihi besaran yang telah ditetapkan dan dalam pelaksanaan anggaran juga terdapat aturan tertentu yang menetapkan bahwa tidak semua alokasi SBKU riset diberikan bagi suatu proposal riset yang diajukan.

Dalam menentukan besaran yang paling efisien, besaran SBKU disusun berdasarkan kebutuhan riset yang selama ini telah dilakukan atau berdasarkan proposal-proposal riset yang telah diajukan. Dari kisaran besaran tersebut, Kemenkeu c.q DJA melakukan exercise penghitungan secara detail dari kebutuhan penyusunan riset per tahapan riset yang selanjutnya didiskusikan bersama-sama baik dengan pihak internal maupun pihak eksternal DJA. Berdasarkan penghitungan secara detail tersebut, akan diperoleh besaran tertentu dari SBKU riset yang selanjutnya ditetapkan sebagai SBKU yang menjadi lampiran dari Peraturan Menteri Keuangan tentang Standar Biaya Keluaran. Atas besaran SBKU tersebut, kebutuhan dana riset yang telah disusun diharapkan telah sesuai dengan kebutuhan dalam penyusunan riset. 
Di sisi lain, dibuat juga ketentuanketentuan tertentu dalam rangka pengajuan anggaran riset sebagai bentuk kontrol dari pengelolaan keuangan negara. Ketentuan tersebut diantaranya ialahmenentukan grade riset dan besaran SBKU yang diberikan berdasarkan grade tersebut. Artinya, dari proposal riset yang diajukan, proposal akan direview oleh reviewerdan akan ditentukan grade risetnya. Selanjutnya berdasarkan grade yang telah ditentukan, akan diberikan persentase besaran SBKU tertentu, misalnya riset grade $A$ memperoleh $35 \%$ dari besaran SBKU riset, riset grade B memperoleh $50 \%$ dari besaran SBKU riset, dan lain sebagainya.

Berdasarkan uraian di atas, dilihat dari proses penentuan besaran SBKU riset, pertanggungjawaban dana secara global, tidak akan menimbulkan pro kontra karena besaran SBKU riset disusun dengan metode yang cukup memadai sehingga menghasilkan besaran SBKU yang dinilai paling efisien. Informasi ini perlu disosialisasikan pada seluruh $\mathrm{K} / \mathrm{L}$ sehingga memiliki persepsi yang sama atas SBKU riset.

\section{b. Akuntabilitas}

Isu selanjutnya yang menjadi perhatian adalah akuntabilitas dari pertanggungjawaban penggunaan dana riset secara global. Pertanggungjawaban tanpa menyertakan bukti-bukti pembayaran secara rinci akan menimbulkan moral hazard atau perilaku seseorang yang tidak peduli dengan suatu risiko atau kerugian yang timbul. Artinya, dengan adanya kebijakan ini, justru dimanfaatkan oleh beberapa pihak untuk mengambil keuntungan sebanyakbanyaknya. Hal ini menyebabkan tidak terjaminnya akuntabilitas dari pertanggungjawaban dana riset.

Menjawab atas kekhawatiran tersebut, setiap kebijakan tentu saja selalu timbul moral hazard yang menyebabkan kebijakan tersebut tidak berjalan secara sempurna. Berkenaan dengan kebijakan pertanggungjawaban dana riset secara global, timbulnya moral hazard dapat diminimalisirkan dalam proses persetujuan suatu pengajuan dana riset melalui reviewer atas proposal riset yang diajukan. Selain itu, dari proses penetapan besaran SBKU riset sendiri pun sudah dimulai diantisipasi dengan menentukan besaran SBKU yang dinilai paling efisien dan optimal.

Dengan demikian, isu akuntabilitas yang muncul akibat adanya pertanggungjawaban secara global dari penggunaan dana riset, sudah dapat dimitigasi risikonya. Maka pembentukan pertanggungjawaban dana secara global, tidak akan menimbulkan pro kontra dari sisi akuntabilitas. Hal ini juga penting untuk diinformasikan kepada pihak pemeriksa, sehingga terdapat pemahaman yang sama dan tidak mempermasalahkan di masa yang akan datang.

\section{c. Pengukuran Kinerja}

Isu terakhir yang muncul dari adanya kebijakan penerapan fleksibilitas pertanggungjawaban penggunaan dana bagi SBKU riset adalah hilangnya alat yang dapat digunakan Menteri Keuangan sebagai chief Financial Officer (CFO) dalam mengukur efisiensi melalui analisis varian. Analisis varian merupakan penghitungan 
dengan membandingkan biaya output, tahapan pencapaian output, dan detail biaya pada saat perencanaan dan pelaksanaannya. Analisis varian merupakan salah satu alat yang digunakan untuk menilai efisiensi yang membandingkan biaya suatu output dari dimensi antarwaktu, tempat, dan pengguna anggaran sebagai pelaksana pencapaian output.

Perhitungan dengan alat ini tidak dapat dilakukan karena tidak ada informasi detail mengenai komponen biaya yang digunakan dari dana insentif riset yang telah digunakan oleh peneliti. Hal ini terjadi karena pertanggungjawaban yang diberikan oleh peneliti hanya berupa penggunaan dana global dengan capaian penyusunan risetnya.

Atas permasalahan tersebut, solusi yang dapat diberikan yaitu dengan tetap mewajibkan para peneliti untuk memberikan rincian komponen biaya atas penggunaan dana insentif riset yang diperolehnya. Rincian tersebut berupa ringkasan penggunaan dana seperti untuk pembiayaan perjalanan dinas, biaya ATK, biaya pengadaan, dan lain sebagainya namun tidak perlu menyertakan buktibukti pembayaran atas pembelian barang atau penggunaan jasa tertentu. Dengan demikian, dengan adanya rincian biaya tersebut, penghitungan efisiensi dapat dilakukan dan selain itu, isu atas kurangnya akuntabilitas penggunaan dana riset juga dapat diminimalisir.

\section{KESIMPULAN DAN SARAN}

\subsection{Kesimpulan}

Berdasarkan beberapa uraian di atas, berikut kesimpulan yang dapat diperoleh yaitu:

1. Konsep penerapan fleksibilitas pertanggungjawaban penggunaan dana untuk SBKU riset adalah serupa dengan pertanggungjawaban pada akun belanja lain-lain. Dengan demikian, pertanggungjawaban atas penggunaan riset hanya berupa penggunaan dana secara gelondongan dan tidak perlu terdapat bukti-bukti pembayaran suatu barang/jasa yang digunakan seperti nota, kuitansi, dan struk. Pertanggungjawaban atas penggunaan dana riset hanya berupa kesepakatan 2 pihak antara PPK dengan penerima insentif riset

Pertanggungjawaban atas penggunaan dana riset hanya berupa kesepakatan 2 pihak antara PPK dengan penerima insentif riset. Kesepakatan tersebut berisi diantaranya progress penyelesaian riset, persentase dana yang dapat dicairkan per progress riset, waktu penyelesaian riset, tenggat waktu keterlambatan, konsekuensi apabila riset terlambat diselesaikan atau tidak dapat diselesaikan, dan hal lainnya yang mengikat bagi penerima insentif riset.

2. Berdasarkan beberapa analisis dari beberapa peraturan perundangundangan yaitu PP No.45 Tahun 2013 dan PMK No.214/PMK.05/2013, penerapan fleksibilitas

pertanggungjawaban penggunaan 
dana untuk SBKU riset tidak memiliki permasalahan yang berarti dari sisi hukum. Hanya perlu terdapat koordinasi antara pihak-pihak terkait terutama DJPB sebagai pengelola BAS. Selain itu juga diperlukan sosialisasi bagi seluruh pengelola keuangan negara terkait hal ini mengingat SBKU akan berlaku bagi seluruh KL. Di samping itu, juga perlu terdapat komunikasi intensif dengan aparat dan pemeriksa agar memiliki cara pandang yang sama pada saat melakukan audit atas pelaksanaan kegiatan dalam rangka pencapaian output riset.

3. Dilihat dari urgensinya, penerapan fleksibilitas pertanggungjawaban penggunaan dana bagi SBKU riset dapat dilakukan. Namun perlu ditekankan pada para peneliti bahwa dengan konsep pertanggungjawaban secara global, harus tetap mengedepankan asas pengelolaan keuangan negara sesuai UU No.17 Tahun 2003 yaitu keuangan negara dikelola secara tertib, taat pada peraturan perundang-undangan, efisien, ekonomis, efektif, transparan, dan bertanggung jawab dengan memperhatikan rasa keadilan dan kepatutan.

4. Terdapat 3 isu yang muncul dalam penerapan fleksibilitas pertanggungjawaban penggunaan dana bagi SBKU riset yaitu penentuan besaran SBKU riset, akuntabilitas, dan pengukuran kinerja. Isu-isu tersebut muncul akibat adanya kekhawatiran bahwa adanya fleksibilitas justru akan menimbulkan moral hazard dari para peneliti untuk menggunakan dana riset secara tidak bertanggung jawab, kurangnya akuntabilitas, dan hilangnya alat bagi Menkeu dalam rangka menghitung efisiensi melalui analisis varian. Namun demikian dari setiap isu telah dapat mitigasi risikonya sehingga diharapkan di masa yang akan datang tidak lagi muncul permasalahan

\subsection{Saran}

Atas beberapa kesimpulan yang telah diambil tersebut, berikut saran yang dapat diberikan yaitu:

6. Saat fleksibilitas terhadap pertanggungjawaban penggunaan dana SBKU riset direalisasikan, perlu terdapat kontrol yang baik sehingga akuntabilitas tetap terjaga.

7. Harus terdapat sosialisasi yang dilakukan dalam memberikan pemahaman yang tepat kepada seluruh pihak yang terkait dengan kebijakan ini. Beberapa pihak diantaranya, pihak Kemenristekdikti, JFA peneliti, pihak universitas atau akademisi, pihak pemeriksa, BPK, Itjen, dan pihak-pihak lain yang berkepentingan, agar terdapat pemahaman yang sama sehingga terjadinya moral hazard dapat diminimalisirkan.

\section{DAFTAR PUSTAKA}

Undang-Undang Nomor 17 Tahun 2003 tentang Keuangan Negara

Peraturan Presiden Nomor 54 Tahun 2010 tentang Pengadaan Barang dan Jasa Pemerintah

Peraturan Pemerintah Nomor 45 Tahun 2013 tentang Tata Cara Pelaksanaan APBN 
Peraturan Menteri Keuangan Nomor 71/PMK.02/2013 tentang Pedoman Standar Biaya, Standar Struktur Biaya, dan Indeksasi Dalam Penyusunan RKA K/L
Peraturan Menteri Keuangan Nomor 214/PMK.05/2013 tentang Bagan Akun Standar 